UDC: $365.24(735.964 .1)$

DOI: 10.5379/urbani-izziv-en-2013-24-01-001

Received: 30 August 2012

Accepted: 19 September 2012

Huston John GIBSON

Yanmei LI

\title{
Opportunities for the United States condominium foreclosure market to provide amenable affordable housing options: The case of Tampa/Hillsborough, Florida
}

Residential foreclosure has been a serious issue during the recent economic recession in the United States, with a profound impact on individuals, households and communities. Various programs are being advocated and implemented to alleviate vacancy problems associated with concentrated foreclosures. This article explores how foreclosed condominiums might help provide affordable housing opportunities in urbanised areas of the U.S. We compare the selling prices of foreclosed and non-foreclosed condominiums in Tampa/Hillsborough, Florida, and then follow up with a neighbourhood study for four selected condominiums to assess their potential as amenable affordable housing options. It is found that foreclosed condominiums, although they do not have an overall statistically significant discount in market price, do show promise for potential affordable housing provision. The article contributes to the current discussion on foreclosures, vacancy and neighbourhood decline issues, and it especially seeks to offer policy implications in markets with a large stock of vacant condominiums but not enough affordable housing. However, the paper also acknowledges potential obstacles facing local communities when converting foreclosed condominiums into affordable housing.

Key words: housing affordability, condominiums, United States foreclosure market 


\section{Introduction}

Following the crisis in the housing and financial market after the second quarter of 2007, millions of owners have experienced foreclosures on their residential mortgages and have abandoned their homes or investment properties (Wallison, 2009; Mehaffy \& Haas, 2012). The results are twofold: 1) a large stock of vacant housing, and 2) many families in need of a residence they can afford. This paper focuses on the possible use of the large vacant condominium housing stock to provide affordable housing.

Affordable housing comprises housing units with a monthly cost of not more than $30 \%$ of a household's gross income, a standard set by the U.S. Department of Housing and Urban Development (Housing and Urban Development, 2010). The supply of affordable housing in this case mostly focuses on low-to-moderate income households. This article provides a first look at how condominiums might satisfy affordable housing needs for a range of families, depending on the price structure and physical design of the unit. Housing affordability measures whether a family household earning the national median family income can qualify for a mortgage on a typical median-priced residence (National Association of Realtors, 2012). This is measured by the National Association of Realtors housing affordability index.

\subsection{Background}

Delinquencies and foreclosures started rising sharply after the market crash shortly before 2010. In the fourth quarter of 2006 , about $0.54 \%$ (2.00\% subprime loans) of total mortgage loans entered foreclosure. About 0.83\% (3.44\% for conventional subprime loans) of all mortgage loans entered foreclosure during the fourth quarter of 2007, and the number rose to $1.08 \%$ (3.96\% for conventional subprime loans) in the fourth quarter of 2008 and $1.40 \%$ (3.66\% for conventional subprime loans) in 2009. ${ }^{[1]}$ Factors contributing to foreclosures have also become more complicated, shifting from housing bubbles and subprime lending to job losses and the unemployment rate during the recession. In 2010, an estimated additional two million homes went into foreclosure. Foreclosures follow certain distinct geographical patterns and are concentrated in Rustbelt and Sunbelt states (Realtytrac, 2008). Although it is not known what specifically caused the concentration of foreclosures in these areas, job losses from economic restructuring in the Rustbelt and the construction boom and housing price bubbles in the Sunbelt states have probably contributed to the foreclosure crisis (Davis, 2010; Foote et al., 2010).
Florida has been among the top foreclosure markets since 2006, following the housing boom between 2001 and 2005, when many condominiums were built or converted from hotels or multifamily rental units. Because these types of projects take time, many were not completed until late 2007 or early 2008. During the housing boom from 2001 and 2005, the discrepancy between price inflation and lagging real income made houses unaffordable for many in Florida. Housing prices in Florida increased by $90 \%$ from July 2001 to July 2006. ${ }^{[2]}$ As a result, rental inventory supply began to decrease. A housing bust should theoretically make housing more affordable. Based on the National Association of Realtors housing affordability index, the bust reached its peak in 2009. However, the difficulty in securing financing and weakened consumer confidence slowed down housing transactions despite the fact that homes were more affordable. For condo developers, speculators and owners, the 2006 real estate bust left many unoccupied units across the state, saturating the market. During the housing and financial crisis between 2007 and 2009, many lenders filed for foreclosures on condominiums. However, tightened underwriting standards and lender unwillingness to pay past-due condo fees to foreclose condominiums meant the foreclosure resale market has been very soft, with a large discount compared to other similar foreclosed properties. In this situation, we have two ways of looking at the current situation: 1) as a devastating crisis for developers, property owners, investors, neighbourhoods and local communities, or 2) as an opportunity for state and local governments to address the growing affordable homeownership gap present in many Florida communities because many of the foreclosed properties were sold at a deep discount (Allen \& Swisher, 2000; Immergluck \& Smith, 2006a, 2006b; Lin et al., 2009). In addition to the first-time homebuyer tax credit and the expanded second-home tax credit, housing transactions have alleviated some of the housing overstock. ${ }^{[3]}$ Florida ranked number four in the nation in terms of per capita First Time Homebuyer Tax Credit during 2008 and 2009 (White, 2009), which indicates that recession, and especially foreclosed houses, might have provided homeownership opportunities for households that otherwise would not be able to afford to own a home. Furthermore, the dense multifamily, abundant and suburban/urban nature of condominiums makes them feasible as affordable housing because of unit cost, complex package-deal possibilities and community accessibility. Much of the previous literature focuses on the negative impacts of foreclosures, but few have attempted to address potential opportunities (such as providing affordable housing) that the crisis might generate.

Several obstacles prevent the inventory of foreclosed houses, especially condominiums, from serving as affordable housing stock for moderate-income households. The first time homebuyer and second home tax credits expired was on 30 April 2010. The market feared that this would slow down 
home purchases and thus lead to a further drop in housing prices in 2010 before the economy recovered from the recession. On the other hand, rising job losses continued to dampen economic recovery. On the supply side, financial institutions tightened credit access and underwriting standards in mortgages, thus making it more difficult for homebuyers to secure mortgages. These institutions not only stopped using various exotic financial tools and originating subprime loans, but also significantly raised down payments, credit scores/history and employment requirements. The secondary mortgage market will be greatly affected once the federal Government-Sponsored Enterprises (GSEs) stop purchasing certain mortgages in order to bundle them as Mortgage-Backed Securities (MBS). Condominium markets are especially suffering from the more stringent underwriting standards. Converting condominiums to affordable housing will also be negatively affected by various condominium fees and regulations imposed by condominium associations.

Although there may be fewer individual buyers, there are bulk buyers purchasing these condos as investment properties. The bulk buyers may not need to go through the strict underwriting process if they have large amounts of investment capital. One outcome of bulk buying is a reduced housing supply and thus a potential increase in housing prices and rents. Stringent underwriting standards will mostly affect moderate-income households or households with limited down-payment savings looking to buy a condo, not bulk buyers.

The literature covers subprime lending and foreclosures quite well, how foreclosure affects property values and neighbourhoods, but only a few studies focus on foreclosure itself. All of the studies reviewed focused solely on single-family homes, and none focused on foreclosures relating to other housing types, particularly condominiums, possibly because of a lack of reliable data on condo foreclosures and lenders being unwilling to foreclose on delinquent condos because they would have to pay condo association fees. To fill the research gap where few have viewed foreclosures as opportunities and to explore the possibility of converting condominiums to affordable housing by overcoming obstacles, this paper uses a sample of 2008 condo transactions in Hillsborough County (greater Tampa), which has seen consistent issues with foreclosure during the economic recession. Transactions are recorded as a) an arms-length transaction, b) a bank-owned transaction, or c) a transaction to prevent a foreclosure. The paper addresses the following research questions: 1) Are the selling prices of bank-owned and/or short sale condominiums comparable to qualified market condominium transactions, and what are the typical price ranges for these properties? 2) Is there potential for the condo foreclosure crisis to help alleviate the need for affordable housing? ${ }^{[4]}$
This paper starts with a brief overview of previous research in the foreclosure resale market, especially the condominium market. Then it introduces the link between affordable housing and the condominium market (especially the condominium foreclosure market) by exploring traditional pricing models of condominiums and how condominiums, particularly condominiums in foreclosure, can provide opportunities for affordable housing. Data, methodology and research results follow, and then the paper discusses planning implications.

\subsection{Foreclosure resale market}

Foreclosed properties are usually sold at a discount compared to other similar properties in the same or nearby neighbourhoods (Forgey, 1994; Carroll et al., 1995). In addition, the Federal Housing Administration (FHA) foreclosed on properties, and the properties in the neighbourhoods where these FHA properties are located are usually sold at a higher discount (i.e., a lower price) than properties with conventional loans. Inefficient marketing by the U.S. Department of Housing and Urban Development (HUD), being sold "as is", being vacant for longer periods, being located in more distressed neighbourhoods, and buyers' biases about FHA properties cause FHA-insured properties to sell at this deeper discount (Carroll et al., 1995). Anthony Pennington-Cross (2003) found that properties with loans that foreclose early in their life were sold at the highest discount, and properties in states requiring the judicial process of foreclosure are sold for less than those sold in states that do not require the legal process. He also found that a more accurate appraisal of properties with low down-payment loans leads to a lower discount in foreclosure resale. The discount even on one foreclosed property affects property values. A cluster of such properties multiplies the effect (Schuetz et al., 2008; Harding et al., 2009).

In addition to the market pricing of foreclosed properties, a few scholars have explored the mechanism of foreclosure auction pricing. Auction prices of foreclosed properties presumably have a deeper discount than foreclosed properties sold on an open market. Marcus T. Allen and Judith Swisher (2000) found that HUD auction properties were sold at a deeper discount (on average $17.45 \%$ lower than predicted market values) than predicted market values of these properties, although this does not indicate that HUD auction homes relate to a distressed housing market. Allen and Swisher (2000) indicated that the discount might be geographically bound. They found that in southern Florida the discount was the largest along the west coast, compared to the smallest among those in Miami-Dade County. Their research was conducted when the housing market was stable, and so the mechanism of auction during the current financial and housing crisis might differ. 
Research notes that, in general, foreclosed properties were sold at a discount, although the size of the discount varied in different markets and studies (Shilling et al., 1990; Forgey et al., 1994; Carroll et al., 1995; Hardin \& Wolverton, 1996; Allen \& Swisher, 2000; Immergluck \& Smith, 2006a). The discount is largely determined by seller motivation and Real Estate Owned (REO) lenders' willingness to accept a liquidating discount to sell the property quickly (Shilling et al., 1990). However, few have explored the extent of the discount based on varying geographical markets and types of properties, although William G. Hardin and Marvin L. Wolverton (1996) found that foreclosed apartment complexes were sold at a $22 \%$ discount compared to non-foreclosure apartments. No previous research has investigated whether condominium foreclosure resale has a deeper discount than other types of housing, which would provide opportunities in affordable housing.

Foreclosed properties, no matter whether they are short sales, auction sales or REO sales, were sold at a discount. Moreover, foreclosure properties also sell faster than properties sold under normal conditions (Springer, 1996), especially during a housing crisis when a large portion of housing transactions are foreclosures. However, the timeframe from filing foreclosures to auction and REO sales was usually very long, which made it difficult to quickly turn over distressed properties. On average, it takes about 28 months before a foreclosed property becomes REO, and then another six months to sell as an REO property (Pennington-Cross, 2003).

\subsection{Affordable homeownership and condominiums}

Although a number of different techniques can provide affordable housing, it remains an issue in many parts of the country, especially when housing prices increase sharply while the increase in median household income lags. A lack of affordable housing stems from the disequilibrium of the housing market when supply and demand are not well balanced. During the housing and economic booms, high profit and the shortage of certain types of housing drove up new construction and encouraged a rush to convert multifamily housing to condominiums in many southern states. This generated oversupply and low absorption rates of housing stock. When the housing bubble burst, the decrease in housing prices would have made condominiums more affordable if economic conditions had been solid.

Housing can be made affordable from both the supply and demand sides (Nelson, 1994). Low-income-housing tax credits, community land trusts, shared equity housing and housing subsidies such as down-payment assistance and Section 8 housing vouchers have helped alleviate the affordable housing crisis in some areas. However, these techniques have their own limitations. Condominiums and townhouses have been viable in helping provide affordable housing because, in general, their prices tend to be lower than comparable single-family homes. This is especially true in dynamic and hot housing markets such as in Nevada, California, Florida, Washington, D.C. and New York City. Most condominiums are in close proximity to downtown areas and thus provide easy access to employment and public transit. In general, condominiums and multifamily housing provide affordable opportunities because of location and high-density development.

During the economic and financial crisis starting in 2007, to help preserve affordable housing stock, the U.S. Congress passed the National Affordable Housing Trust Fund Act. Many believed that foreclosed vacant properties could be successfully converted to affordable housing using innovations such as partnerships and land-banking programs (Carr, 2008; Poethig, 2010). Houses did decrease in price, but affordable housing in Florida remained an issue. In February 2009, about 750,000 families in Florida still needed affordable housing (Padgett, 2009). Increasing numbers of households in foreclosure and more homelessness seriously challenged the rental housing market and affordable housing stock. Tightening mortgage underwriting standards and lack of credit made it even more difficult for these households, even if the prices were low.

Condominiums were hit equally hard during the housing and financial crisis between 2007 and 2009. Between 2003 and 2008, downtown Miami built 23,000 new or converted condos, but only 13,000 had occupants (House Repos, 2009). Although it is not clear how many condo units went into foreclosure, these properties were not immune to the economic downturn. Surprisingly, statistics about foreclosures, especially based on types of housing, are scant, except from certain commercial real estate companies such as Condo Vultures, Inc. A large portion of foreclosed homes are condominiums in places such as Florida and New York City, where the share of condos in the housing stock is large. No academic literature addresses condominium foreclosures, their impact, and whether the foreclosed condo resale market provides arbitrage and speculation opportunities. Moreover, stringent mortgage underwriting standards for condominium purchases mean that decreases in the prices for condos might be more significant than for other types of housing. The number of condominium foreclosure resales may actually be higher than other types of foreclosure resales. Therefore, a large portion of vacant condominium stock might remain on the market. This sluggish condominium foreclosure resale market calls for policy interventions to help reuse these properties. As an innovative neighbourhood stabilisation strategy, converting condominiums to affordable hous- 
ing faces various challenges: insufficient funding sources and competition with bulk condo investors (Gerrity, 2010). Successful condo conversion to affordable housing relies on strong public-private partnerships. The Neighborhood Stabilization Program alone is not sufficient to fill the gap between affordable housing needs and the availability of affordable homes. In the city of Lawrence, Massachusetts, for example, converting and renovating four historical condo buildings largely depended on collaboration among Lawrence Community Works, the city of Lawrence, the Commonwealth of Massachusetts, the Massachusetts Housing Investment Corporation, Enterprise Bank and NeighborWorks America (Betances, 2010).

In New York City, where affordable low-income housing is an ongoing issue, many advocate converting vacant luxury condos, some of which were developed in low-income neighbourhoods during the housing boom, into affordable housing (Katz, 2009). The Right to the City Alliance (2010) estimates about 4,092 vacant condo units in six districts in New York City and recommended converting some of them into affordable housing in 2010. In 2009, the city committed USD 20 million of city funds to convert 400 condo units into affordable housing. If the pilot project is successful, more projects will follow (House Repos, 2009). To avoid competing with private condo buyers, the City of New York most likely will focus on cheaper and less competitive small condo buildings to convert to affordable housing (Anderson, 2010). However, initiatives such as these have not gained impetus in Florida, where condo vacancies remain an issue.

\section{Materials and methodology}

This study asks the following questions: 1) Are the selling prices of bank-owned and/or short sale condominiums comparable to qualified market condominium transactions, and what are the typical price ranges for these properties? 2) Is there potential for the condo foreclosure crisis to help alleviate the need for affordable housing?

The research design for this study was both quantitative and qualitative. First, a cross-sectional study using multivariate regression to explore the relationship between condominium pricing and property transaction status was implemented to address whether foreclosed condominium properties were associated with depressed selling prices, and how affordable they were for low-to-moderate income households. Then, a qualitative case study was conducted to explore how foreclosure transactions are linked to affordable housing provisions. These two separate methods were designed to address our two research questions.
We used the market value of condominiums to assess factors contributing to pricing. This primarily included property selling price data in 2008 from the Florida Department of Revenue (FL-DOR) tax roll archives and demographic data collected by the U.S. Census Bureau. FL-DOR annually records the monetary selling prices for all real estate transactions in Florida as reported by local county property appraisers' offices. The property selling prices were merged with FL-DOR Geographic Information Systems (GIS) parcel files to identify general property locations and with 2008 US Census estimate data to control for demographic factors.

The first section applied a cross-sectional multivariate regression model as follows (Model 1):

$$
\begin{array}{r}
\text { selling price }=\mathrm{B}_{0}+\mathrm{B}_{1}(\text { living space })+\mathrm{B}_{2}(\text { year built })+\mathrm{B}_{3}(\text { distance } \\
\text { from cbd } \left.)+\mathrm{B}_{4}(\text { distance from coast })+\mathrm{B}_{5} \text { (jurisdiction }\right)+ \\
\mathrm{B}_{6}(\text { race })+\mathrm{B}_{7}(\text { rent/own })+\mathrm{B}_{8}(\text { medium income })+ \\
\mathrm{B}_{9}(\text { transaction status })+\mathrm{B}_{10}(\text { month of transaction })+\mathrm{e}
\end{array}
$$

Table 1 lists and briefly describes all study variables and the data sources. Table 2 displays descriptive statistics. The dependent variable in this part of the study was the selling price of individual condominium units in Tampa/Hillsborough County in the state of Florida. There were a total of 254 complete observations in the study sample. ${ }^{[5]}$ The Hillsborough County unincorporated area had $80 \%$ (203) of the observations; the city of Tampa had 17\% (43). In addition, the city of Temple Terrace, a second incorporated municipality in the county, had $3 \%$ (8). City/county was appropriate for the study because the area is a midsized metropolitan area with suburbs, lending itself to generalisations to broader populations of similar Florida and American cities. ${ }^{[6]}$ The range of selling prices for the condos included in the model was from USD 10,000 to USD 567,000, with a median selling price of USD 278,500. The average selling price in the sample was USD 89,628, with a standard deviation of USD 61,212. For comparison, the average selling price for the same (set) price range of single-family housing in this geography, during the same timeframe, was USD 192,762 with a standard deviation of USD 101,745 (actually range USD 14,000 to USD 565,000; $N=2,107$ ).

The month of transaction was included to control for the seasonality of unit transactions. This is a dummy variable based on the month of the sale. The months January (1) through May (5) were included in this study. This timeframe covers a cross-section of the first winter/spring "season" after the 2007 housing and financial market crash. ${ }^{\left[{ }^{8}\right]}$

The housing unit control variables used for analysis were living space and the age of the unit. While other unit characteristics may influence selling price and be considered for study, these 
two attributes control for the lion's share of individual unit characteristics, such as number of possible bedrooms or basic architectural period trends. Locational neighbourhood control variables used for analysis were the home's distance from the Central Business District (CBD), distance from the coast and taxing jurisdiction. These variables were intended to control for commutes to downtown and water recreation, as well as jurisdictional services rendered / fees paid. Also included were census block geography-based characteristics of race (percent non-White), median income, and percent of owner-occupancy to control for general neighbourhood demographics. In addition, the standard errors are clustered by census block to ac- count for region-specific effects that are unique to each neighbourhood, and the neighbourhood's effect on selling price of condo. The key independent variable of interest, transaction status, was a dummy variable that denotes whether or not the unit transaction was under foreclosure-related circumstances at the time of the sale.

\subsection{Transformations from diagnostics}

Two model transformations were made as a result of OLS diagnostics. First, a visual review of a histogram of the dependent variable, selling price, indicated that the sample was positively

Table 1: Description of variables

\begin{tabular}{ll}
\hline Variable & Description \\
\hline Selling price (d.v.) & Dollar (USD) amount of real estate transaction, for individual units \\
\hline Living space & Total indoor living space, $\mathrm{m}^{2}$ \\
\hline Year built & Year unit constructed \\
\hline Distance from CBD & Distance $(\mathrm{m})$, from parcel to centre point in downtown (Tampa) \\
\hline Distance from coast & Distance $(\mathrm{m})$, from parcel to nearest coast \\
\hline Jurisdiction & Dummy variable for taxing jurisdiction (Tampa, Temple Terrace, unincorporated Hillsborough \\
\hline Race & County) \\
\hline Rent/own & Percent non-White \\
\hline Medium income & Percent of owner-occupied residents in census block \\
\hline Transaction status & Medium income (USD) for census block \\
\hline Month & Dummy variable denoting whether or not the unit sold under foreclosure circumstances \\
\hline
\end{tabular}

Note: (d.v.) = dependent variable.

Table 2: Descriptive statistics

\begin{tabular}{lll}
\hline Variable & Range/Label & Mean (Standard Deviation) or Percent (Frequency) \\
\hline Selling price & USD 10,000-USD 567,000 & USD 89,628 (USD 61,212) \\
\hline Living space & $31.59 \mathrm{~m}^{2}-253.25 \mathrm{~m}^{2}$ & $120.31 \mathrm{~m}^{2}\left(37.44 \mathrm{~m}^{2}\right)$ \\
\hline Year built & $1969-2008$ & $1990(11)$ \\
\hline Distance from CBD & $7,735.82 \mathrm{~m}-30,486.71 \mathrm{~m}$ & $21,058.33 \mathrm{~m}(7,033.56 \mathrm{~m})$ \\
\hline Distance from coast & $8.53 \mathrm{~m}-23,535.13 \mathrm{~m}$ & $9,291.83 \mathrm{~m}(5,438.55 \mathrm{~m})$ \\
\hline \multirow{3}{*}{ Jurisdiction } & Tampa & $17 \%(43)$ \\
\cline { 2 - 3 } & Temple Terrace & $3 \%(8)$ \\
\cline { 2 - 3 } & Hillsborough County & $80 \%(203)$ \\
\hline Race & $27 \%-99 \%$ & $77 \%(18 \%)$ \\
\hline Rent/own & $1 \%-98 \%$ & $68 \%(31 \%)$ \\
\hline Median income & USD 23,937-USD 126,438 & USD 52,032 (USD 20,386) \\
\hline \multirow{2}{*}{ Transaction status } & Not under foreclosure circumstances / & $90 \%(229)$ \\
\hline & a qualified transaction* & $10 \%(25)$ \\
\cline { 2 - 3 } & Under foreclosure circumstances & $11 \%(29)$ \\
\hline \multirow{2}{*}{ Month } & January & $16 \%(40)$ \\
\cline { 2 - 3 } & February & $20 \%(50)$ \\
\cline { 2 - 3 } & March & $32 \%(82)$ \\
\cline { 2 - 3 } & April & $21 \%(53)$ \\
\cline { 2 - 3 } & May & \\
\hline
\end{tabular}

Notes: $N=254$; all figures rounded to nearest whole number; $\left(^{*}\right)$ reference category. 
skewed. The prescription of transforming this variable into its logarithmic form for analysis was applied. A Box-Cox transformation was also explored, and produced similar outputs. Second, the unit's year built variable was transformed into age-squared to account for non-linear effects of age on the price of the condominiums. No other transformations were warranted or issues identified.

\section{Results}

\subsection{Condominium pricing and transaction status}

The independent variables in the first model explained 68\% of the selling price variation in Hillsborough County condo transactions from January to May 2008. This was sufficient to provide an indication of the relationship between foreclosure transactions and selling prices. As we expected, units under foreclosure showed a negative association with selling prices; however, the discount was not statistically significant. Table 3 displays the regression outputs of Model 1 . Also of statistical significance, units within the city limits of Tampa correlated positively with selling prices at alpha level $0.01(0.252 ; 0.089)$.

Table 3: Regression outputs from Model 1

\begin{tabular}{|c|c|}
\hline Variable & $\begin{array}{l}\text { Coefficients } \\
\text { (Robust Standard Errors) }\end{array}$ \\
\hline Living space & $\begin{array}{l}0.001^{* * * *} \\
(0.00009)\end{array}$ \\
\hline Age (squared) & $\begin{array}{l}-0.0002^{*} \\
(0.0001)\end{array}$ \\
\hline Distance from CBD & $\begin{array}{l}-5.91^{*} \\
(3.07)\end{array}$ \\
\hline Distance from coast & $\begin{array}{l}-5.84^{* *} \\
(2.86)\end{array}$ \\
\hline Race & $\begin{array}{l}0.948^{* *} \\
(0.4)\end{array}$ \\
\hline Rent/own & $\begin{array}{l}-0.267^{*} \\
(0.16)\end{array}$ \\
\hline Medium income & $\begin{array}{l}-2.61 \\
(1.35)\end{array}$ \\
\hline $\begin{array}{l}\text { Transaction under foreclosure } \\
\text { circumstances }\end{array}$ & $\begin{array}{l}-0.076 \\
(0.085)\end{array}$ \\
\hline $\begin{array}{l}\text { Adjusted } R \text {-square } \\
\text { (Prob }>F=0.000)\end{array}$ & 0.685 \\
\hline
\end{tabular}

Notes: $N=254 ;\left({ }^{*}\right) p<0.1,\left({ }^{* *}\right) p<0.05,\left({ }^{* * *}\right) p<0.01,\left({ }^{* * *}\right) p<0.001$.

In our first model, transaction status was a binary dummy variable that denoted whether or not the unit sold under foreclosure circumstances. In this sample, foreclosure circumstances included any transactions recorded as 1) deeds to or from financial institution (bank-owned) or 2) transaction under extreme circumstances (transaction under threat of bank foreclosure). The difference is that, if the bank owned the property, the home was foreclosed on, but in the other situation the foreclosure process has begun but is not complete. All other transactions in the sample qualified as non-foreclosure circumstances. For our second model, bank-owned and bank-pressured transactions were separated for analysis. Table 4 displays these added descriptive statistics.

Table 4: Descriptive statistics for transactions bank-owned versus bank-pressured

\begin{tabular}{lll}
\hline Variable & Label & Percent (Frequency) \\
\hline \multirow{2}{*}{ Transaction } & $\begin{array}{l}\text { Not under foreclosure } \\
\text { circumstances } \\
\text { qualified }\end{array}$ & $\begin{array}{l}\text { Under foreclosure } \\
\text { circumstances / } \\
\text { bank-owned }\end{array}$ \\
\cline { 2 - 3 } & $\begin{array}{l}\text { Under foreclosure } \\
\text { circumstances / } \\
\text { bank-pressured }\end{array}$ & $2.5 \%(19)$ \\
\hline
\end{tabular}

Notes: $N=254$; all figures rounded to nearest whole number.

When the model was run with this further separation of the transaction variable, we see that bank-owned properties sold at a statistically significant (alpha level .05) discounted price. See Table 5 for transaction regression outputs from Model 2.

Table 5: Transaction regression outputs from Model 2

\begin{tabular}{lll}
\hline Variable & Label & $\begin{array}{l}\text { Coefficients } \\
\text { (Robust Standard Errors) }\end{array}$ \\
\hline \multirow{4}{*}{ Transaction } & $\begin{array}{l}\text { Under foreclosure } \\
\text { circumstances / } \\
\text { bank-owned }\end{array}$ & $\begin{array}{l}-0.185^{*} \\
(0.088)\end{array}$ \\
\cline { 2 - 3 } & $\begin{array}{l}\text { Under foreclosure } \\
\text { circumstances / }\end{array}$ & 0.244 \\
& bank-pressured & $(0.161)$ \\
\hline
\end{tabular}

Notes: $N=254 ;(*) p<0.05$.

Thus it appears that there may be potential for bank-owned condominiums to be an adequate source of affordable housing. This is in line with hypothesised expectations. However, while the regression outputs began to give a glimpse of real estate transaction activity for foreclosure and non-foreclosure condominium properties, they told us little about the characteristics of the property involved or the appropriateness for use as affordable housing. Accordingly, the bank-owned properties were further assessed, qualitatively, to better evaluate whether these discounted units are feasible for affordable housing.

\subsection{Foreclosure resale and affordable housing provision}

The decrease in housing price from the housing and financial crisis provided opportunities in affordable housing; however, 
more stringent underwriting standards and diminished consumer spending caused other challenges in housing. In Hillsborough County, more people saw severely burdened housing costs (see Figure 1), meaning households spent more than 50\% of their income on housing and related expenses. In 2008, approximately 49,166 households with income less than $80 \%$ AMI (Area Median Income) were severely burdened; in 2030, the projected number is 68,537 . These households accounted for $16 \%$ of the total renter households and $8 \%$ of the total owner households in Hillsborough County. Renters were particularly vulnerable to housing affordability. Hillsborough County saw a sharp rise in severely burdened households compared to many other counties in Florida, indicating significant needs in affordable housing (Florida Housing Data Clearing House, 2010). The research analysis using multivariate regression models showed Hillsborough County's condo foreclosure resale price had a relatively small discount, imposing further challenges in converting foreclosed homes, especially condominiums, to affordable housing.

\subsection{Condominium foreclosure and providing quality affordable housing}

In Hillsborough County, 258 condominiums were sold during the study period. These transactions are not necessarily taken from auction or REO sales, however. The following study then assessed condo transactions and foreclosures and how they might provide advantages in location and affordability in terms of providing quality and affordable housing.

Our results indicated that many foreclosed and regular condos were in areas with moderate income levels and mostly White, non-Hispanic residents (see Figures 2 and 3), which is quite different from the spatial patterns of overall residential foreclosures. The literature indicates, in general, that residential mortgage foreclosures concentrate in low-income minority neighbourhoods, and thus, without policy and redevelopment intervention, housing stock and neighbourhoods might not be desirable for quality affordable housing (Apgar \& Duda, 2004; Immergluck \& Smith, 2006a, 2006b; Belsky, 2008; Bocian et al., 2008; Chan et al., 2010). On the other hand, condominium foreclosures might provide quality affordable housing opportunities without redevelopment.

Most of these condos were close to downtown and the coast. We also found most of these condos are close to public transit, open space and schools. Unlike other types of housing stock, these condos are also relatively new. All these features indicate the potential of condo foreclosures in increasing affordable housing stock.

In 2009, the AMI (Area Median Income) for Hillsborough County was USD 54,400. Among the 258 condo foreclo-

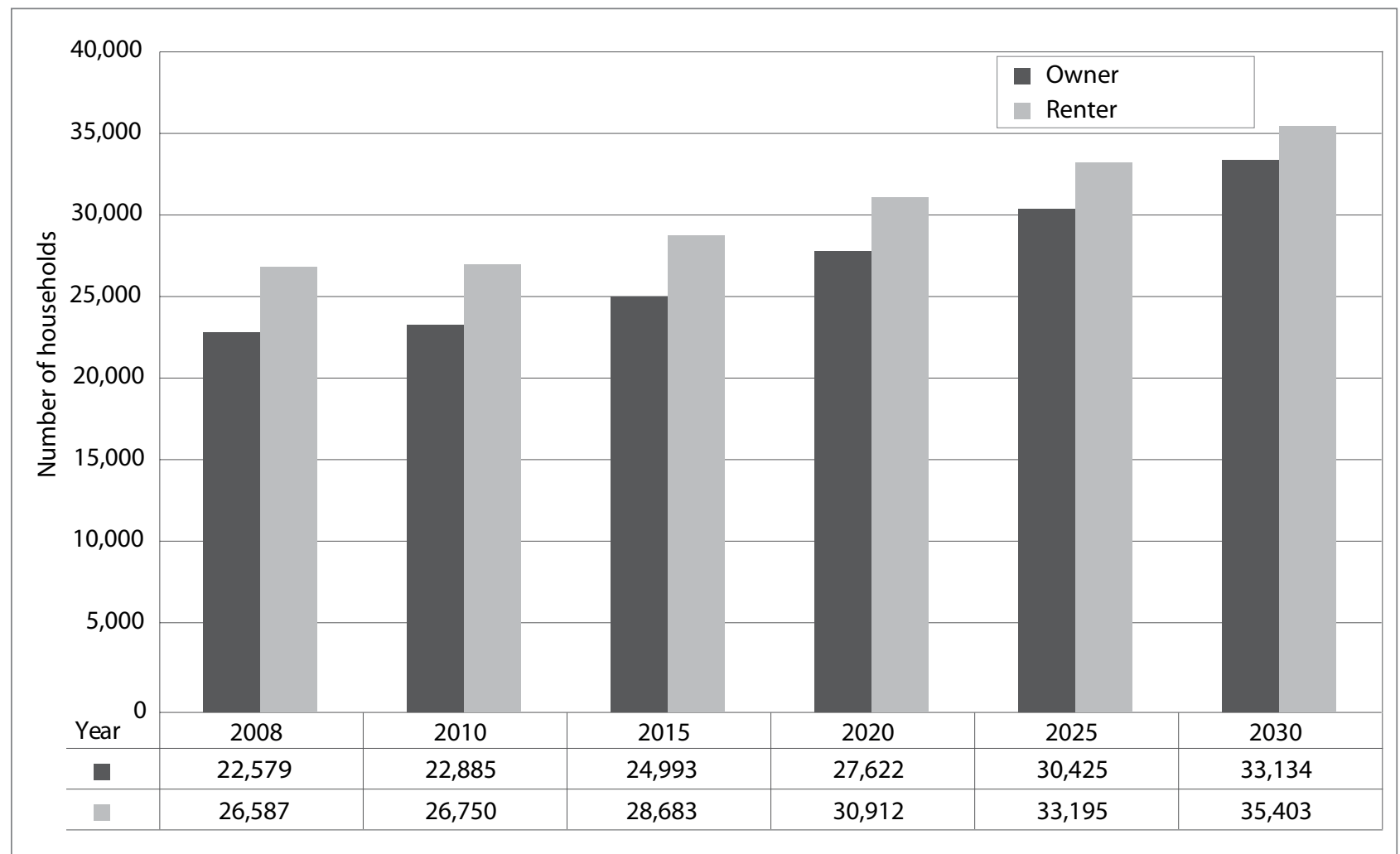

Figure 1: Number of severely cost-burdened $(50 \%+)$ households with income less than $80 \%$ AMI by tenure in Hillsborough County, Florida, 2008-2030 (source: Florida Housing Data Clearing House, 2010). 
sure transactions, 210 sold at for USD 130,560 or less, about three times the recommended $80 \%$ of AMI for housing costs. This indicated that households with less than or equal to $80 \%$ of AMI could afford $81.4 \%$ of these transactions. We then estimated monthly condo costs compared for affordability with households with different income levels. The estimated monthly condo cost includes PITI (mortgage principle, interest, property taxes and property insurance), condo fees and annual maintenance costs. We estimated the monthly mortgage payment based on $80 \%$ LTV (Loan to Value) ratio, $6 \%$ annual interest rate and a thirty-year conventional mortgage. After the housing recession, many mortgage originators required at least a 20\% down payment for condominiums in Florida. Property taxes were then estimated based on the average taxes paid in the county. On average, property owners paid about USD 16.33 per USD 1,000 of assessed housing value. This ratio multiplies assessed housing value to derive estimated annual property taxes. Hazard insurance rates differ among homes significantly because of different housing features. However, in Hillsborough County, the average hazard insurance for a USD 150,000 home was USD 2,135 without wind mitigation policies and USD 1,528 with wind mitigation policies (Shop

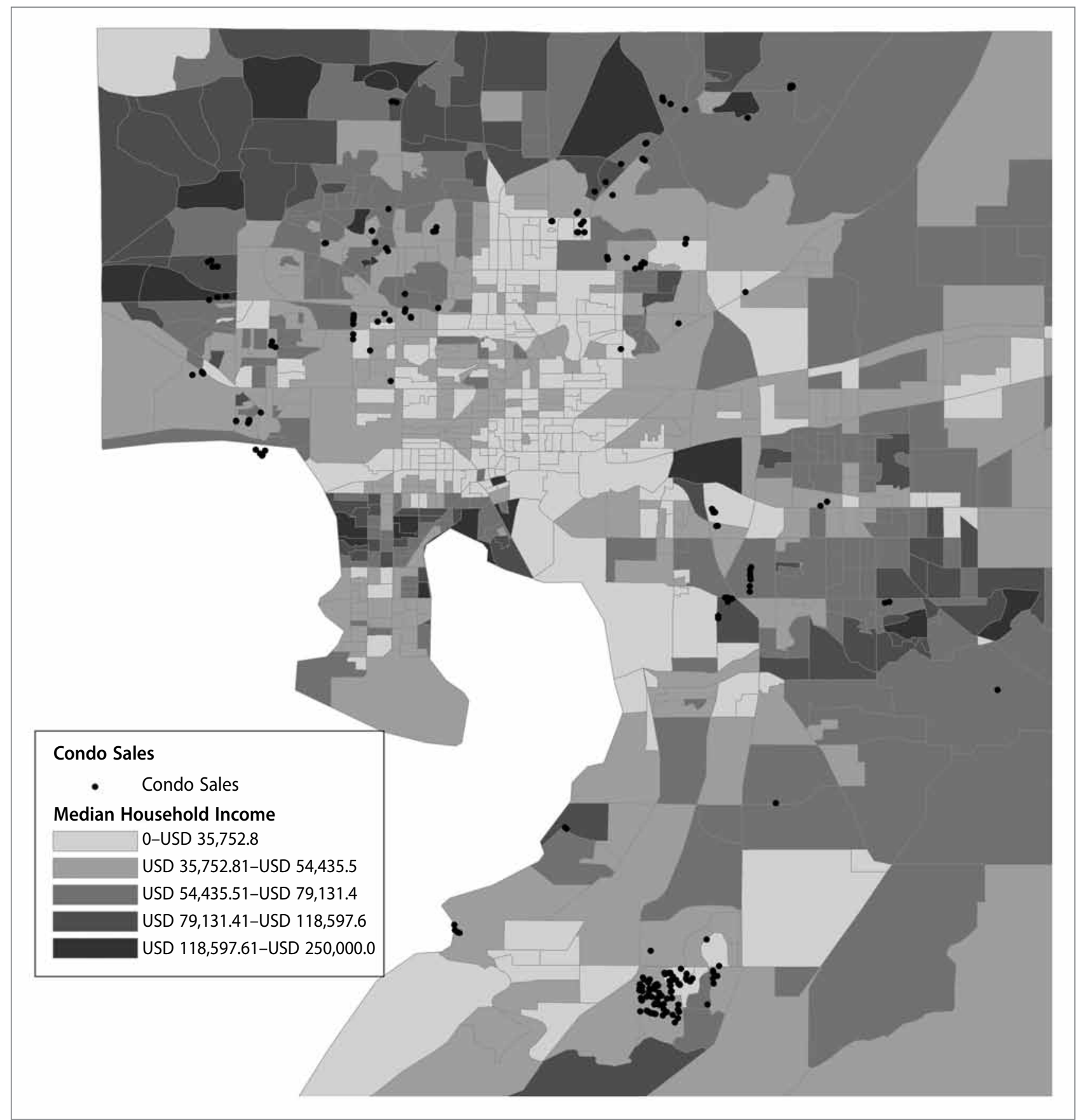

Figure 2: Distribution of condo transactions and median household income. 


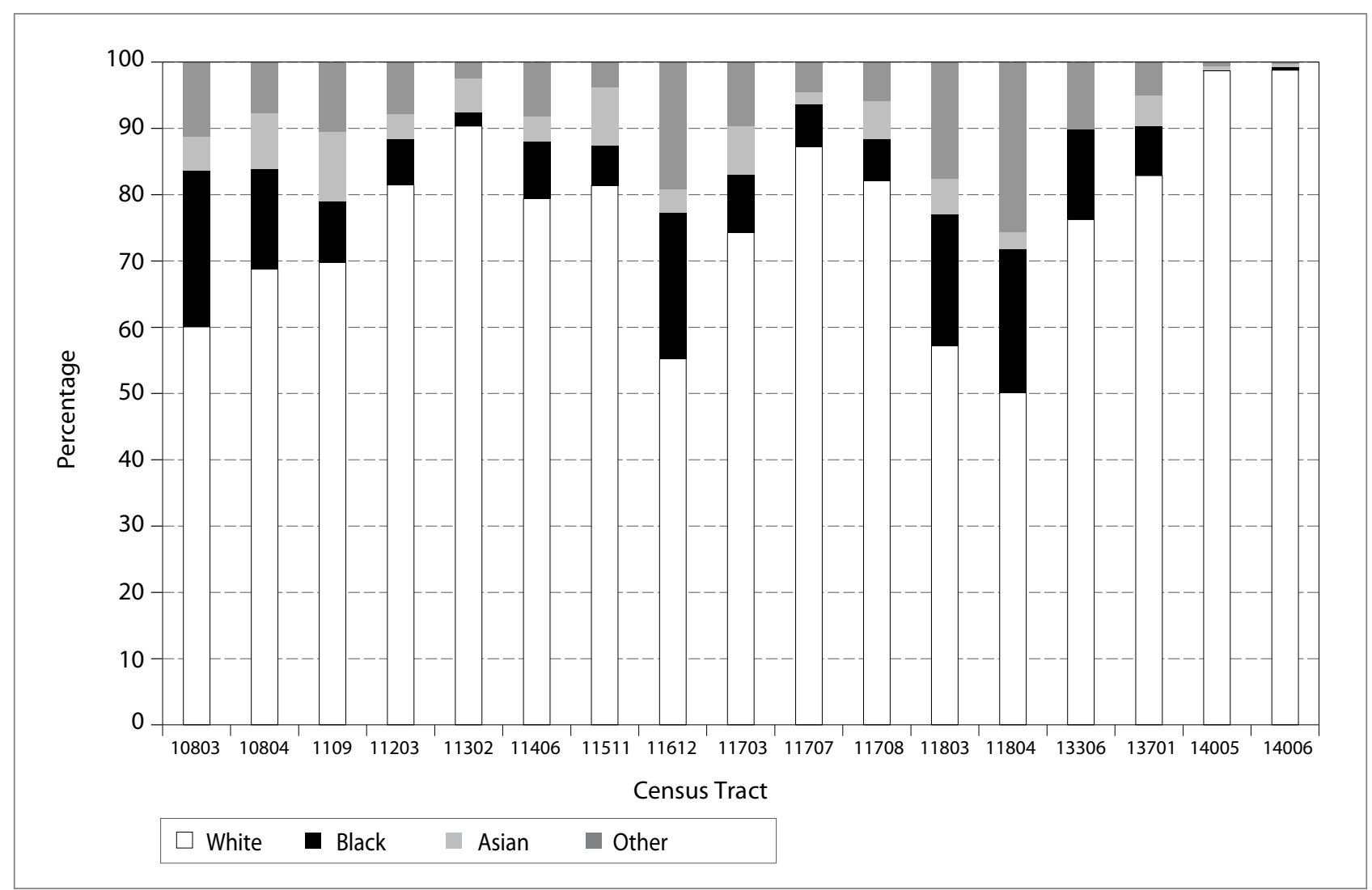

Figure 3: Racial composition of Hillsborough County, Florida, census tracts with condo foreclosures, 2008.

and Compare Rates, 2010). We used an average of USD 1,831 for a USD 150,000 house to estimate insurance premiums for condo homes. Then we assumed about USD 1,000 condo fees, which might be on the conservative side, each year. The annual estimated maintenance costs were about USD 500.

Affordability estimates indicated, among the 258 foreclosed condos, $84.4 \%$ were affordable for households with $80 \%$ of AMI (see Table 6) and particularly for households between $30 \%$ and $80 \%$ of AMI (see Table 6 and Figure 5), thus possibly filling affordable housing stocks for low-to-moderate income households at market values. Households with extremely low income might still need subsidies to afford these condos. Only about $3.9 \%$ of the foreclosed condos could be considered only for households with more than $120 \%$ AMI. This may not be

Table 6: Hillsborough County condominium stock compared to Area Median Income (AMI)

\begin{tabular}{lll}
\hline Income limits & $\begin{array}{l}\text { Number of affordable } \\
\text { condominiums }\end{array}$ & $\begin{array}{l}\text { Affordable } \\
\text { condominiums (\%) }\end{array}$ \\
\hline$>120 \%$ AMI & 10 & 3.9 \\
\hline $100 \%-120 \%$ AMI & 7 & 2.7 \\
\hline $80 \%-100 \%$ AMI & 23 & 8.9 \\
\hline $50 \%-80 \%$ AMI & 85 & 32.9 \\
\hline $30 \%-50 \%$ AMI & 103 & 39.9 \\
\hline$<30 \%$ AMI & 30 & 11.6 \\
\hline
\end{tabular}

the overall pattern of condo foreclosures in Florida, but in Hillsborough County these condos had increased affordable housing stock. Furthermore, the selling price of most of these condos was lower than median housing value for the county (see Figure 4). All of these indicated strong affordability.

\subsection{Neighbourhood case studies}

To supplement the quantitative analysis, a qualitative assessment explored how condo foreclosures might provide affordable housing. Thus, we focus on four neighbourhoods: Somerset Park Condominium, the Enclave at Richmond Place, Brookfield Condominium and Maplewood Condominium. ${ }^{[8]}$ Somerset Park Condominium is about $15 \mathrm{~km}$ northeast of Tampa. It is a neighbourhood with an average income of USD 21,000 (Table 7). The Richmond neighbourhood is about $23 \mathrm{~km}$ northeast of Tampa. It has a slightly higher median household income and the housing values are more diverse. The Brookfield and Maplewood neighbourhoods are close to each other and located about $30 \mathrm{~km}$ east of Tampa. Brookfield and Maplewood are active adult communities and have the largest cluster of condo sales during the study period, with the highest sales price not exceeding USD 170,000. Most of the condos in these four neighbourhoods are affordable to households with less than 100\% AMI (USD 54,400). Detailed auxiliary analysis of these neighbourhoods in the following 


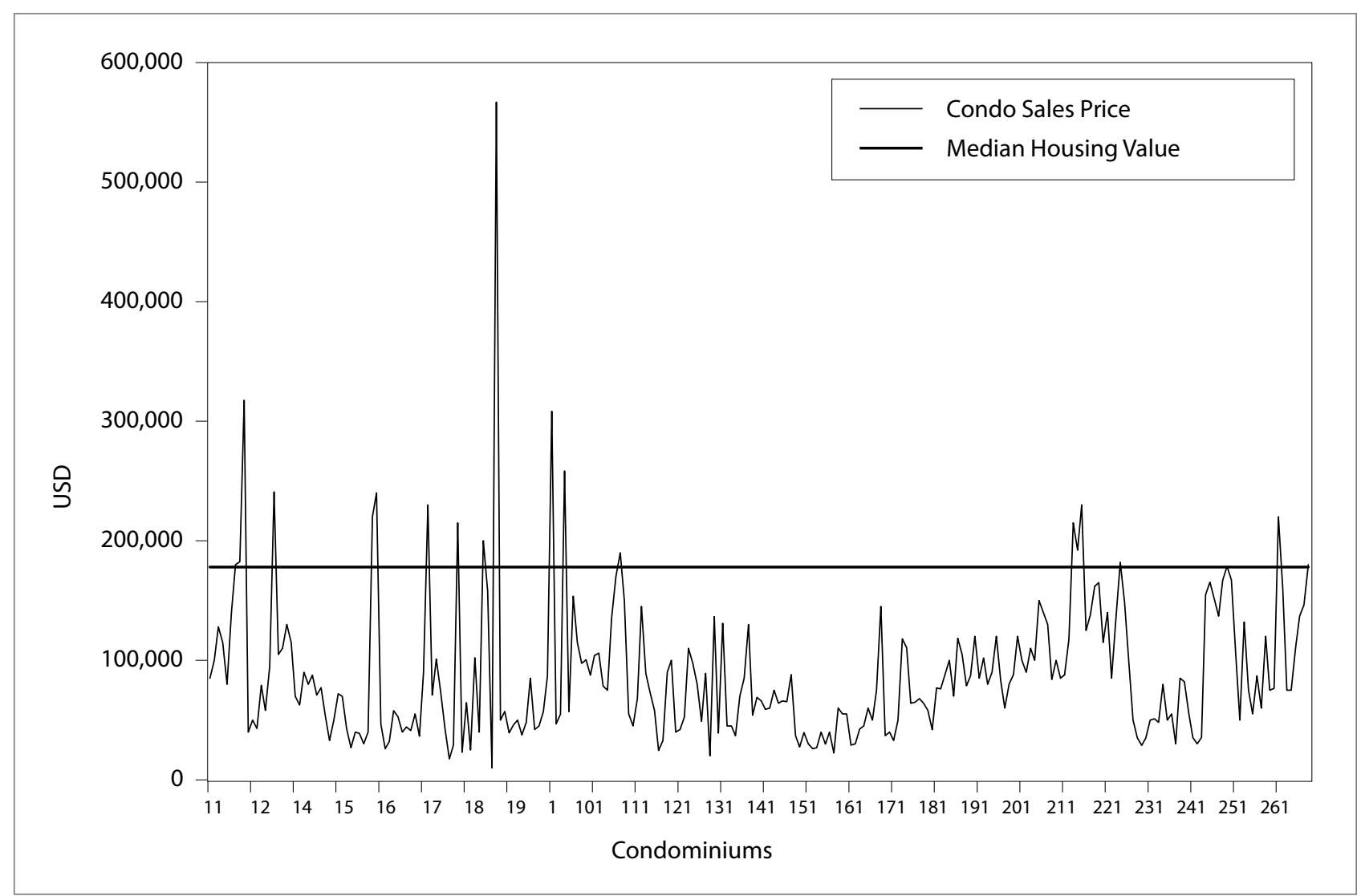

Figure 4: Condo transaction prices compared to median housing value in Hillsborough County, in 2009 dollar value.

Table 7: Descriptive statistics of census block groups for selected neighbourhoods, 2010

\begin{tabular}{lllllll}
\hline Block groups & Percentage white & $\begin{array}{l}\text { Median household } \\
\text { income (USD) }\end{array}$ & $\begin{array}{l}\text { Median house price } \\
\text { (USD) }\end{array}$ & $\begin{array}{l}\text { Average year } \\
\text { built }\end{array}$ & $\begin{array}{l}\text { Distance from } \\
\text { CBD (km) }\end{array}$ & $\begin{array}{l}\text { Distance from } \\
\text { coast (km) }\end{array}$ \\
\hline Somerset & 36.6 & 21,000 & 104,800 & 1980 & 14.81 & 13.68 \\
\hline Richmond & 69.6 & 37,257 & 291,900 & 2004 & 22.69 & 20.60 \\
\hline Brookfield & 97.7 & 32,210 & 178,500 & 2000 & 29.93 & 7.40 \\
\hline Sifield & 97.7 & 32,210 & 178,500 & 2000 & 29.93 & 6.92 \\
\hline
\end{tabular}

Source: United States Census Bureau $(2008,2010)$

section focuses on important amenities attractive to potential low-to-moderate income homebuyers or renters. These amenities play important roles enhancing the quality of life of residents.

The first auxiliary attribute was the walkability of the neighbourhoods. The Walk Score algorithm assigns a walkability score to a property as a calculation of proximity of the property to surrounding community amenities (Walk Score, 2010). This score gives a snapshot of how convenient a location would be without access to an automobile (Duncan et al., 2011). A Walk Score of 90 to 100 is a "walkers' paradise", translating into the notion that residents do not need a car for daily errands. A score of 70 to 89 is considered "very walkable", translating into the notion that residents can run most errands without a car. A score of 50 to 69 is "somewhat walkable", translating into the notion that residents can run some errands on foot. A score of 0 to 49 is "car dependent", translating into the notion that residents need a car for most or all errands (Walk Score, 2010).

Public transit access was the next auxiliary attribute, assessed by locating the nearest transit route to the property. We then determined whether there was a route within $0.8 \mathrm{~km}$ of the complex, giving a dichotomous, "yes/no" variable. Hillsborough County has a public bus system, the Hillsborough Area Regional Transit Authority.

For the next auxiliary attribute, school quality, we used the Florida Department of Education School Grade as the variable measure. Florida School Grade assignments are administered at the countywide school district level under the supervision of the Florida Department of Education. Like most student grading scales, School Grades range from "A" to "F", with "A" being the best and "F" the worst (with no "E" grade). School 


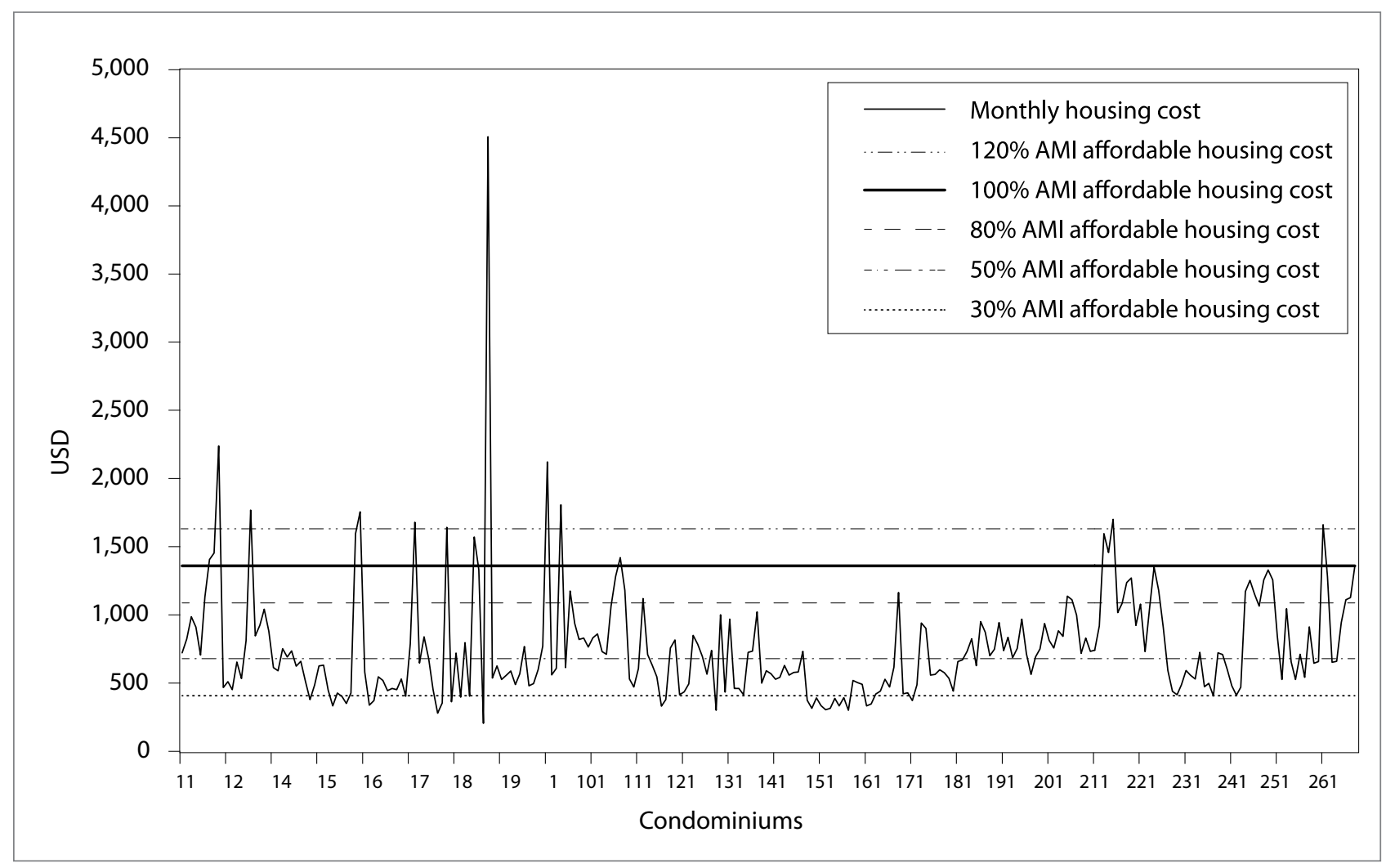

Figure 5: Monthly housing cost comparison between condos in Hillsborough County, Florida, AMI (Area Median Income) housing affordability, in 2009 dollar value.

Grades are based on a combination of the points earned by student achievements on the Florida Comprehensive Assessment Test (FCAT), percent of students tested, and the criteria of Adequate Yearly Progress (AYP) of the No Child Left Behind Act. Grades for all Florida schools are published annually by the Florida Department of Education in School Accountability Reports, which are available to the public on the Florida Department of Education website. We used the most recent school year (2008/09) grade available at time of study. The AMI match was also noted as a variable in the qualitative assessment.

\subsection{Empirical findings of auxiliary attributes}

Table 8 displays the empirical findings for auxiliary attributes for the selected units. To start, we found that all four complexes reviewed had clubhouses, pools, tennis courts and other recreational amenities for the residents. Regarding transportation, although all complexes provided parking, only one complex (Somerset) was near (within $0.8 \mathrm{~km}$ ) a bus stop. Somerset was also the most modestly priced unit. Regarding walkability, two of the units were above the county average, whereas two were well below (0/100). None were in the top $10 \%$ range for the county. The 60s range of the Somerset and Richmond units indicated that these areas were somewhat walkable and that residents could feasibly run some of their errands on foot in these neighbourhoods should they choose. The Sun City Center units were car-dependent, however, with only a few amenities within a reasonably considered walking distance according to their Walk Score.

School quality was variable. The elementary schools were all "A" schools, middle schools were "A" or "C" schools, and the high schools were all "C" schools. Interestingly, schools near the lower-priced units had better School Grades than the higher priced units.

To determine the monthly payment on a unit, we figured a 30 year fixed mortgage at $6.5 \%$ interest. ${ }^{[9]}$ On USD 50,000 this would equal approximately USD 336.87 plus taxes and insurance (Mortgage Calculator, 2010). This means that even with the highest estimates of condo association fees, the monthly housing payments would be less than average area rents, which were approximately USD 900 dollars for a comparable unit at that time (2008).

Because HUD recommends that households spend no more than $30 \%$ of their annual income on housing, even with higher estimated mortgages and condo fees for the lower-priced units of Somerset and Richmond, the monthly payments were less than $30 \%$ of area median household incomes (Housing and 
Table 8: Auxiliary empirical findings for the selected neighbourhoods

\begin{tabular}{lllll}
\hline Variable & Somerset & Richmond & Brookfield & Sifield \\
\hline Amenities & Yes & Yes & Yes & Yes \\
\hline Walkability* & $68 / 100$ & $65 / 100$ & $0 / 100$ & $0 / 100$ \\
\hline Public transit w/in $0.8 \mathrm{~km}$ of complex & Yes & No & No & No \\
\hline Elem. school quality & "A" & "A" & "A" & " $\mathrm{A}$ " \\
\hline Middle school quality & "A" & " $\mathrm{A}$ " & "C" & "C" \\
\hline High school quality & "C" & "C" & "C" & "C"
\end{tabular}

Notes: $\left(^{*}\right)$ County average $=60 / 100$; county top $10 \%=85-100$.

Urban Development, 2010). Furthermore, the costs associated with the Somerset and Richmond foreclosure transactions were well below average (USD 89,628) condo costs in the sample, as well as overall median housing costs in the area (USD 297,943).

Unfortunately, the lowest priced unit in Somerset had the highest Walk Score, best School Grades, the only complex near public transit (yet still with plenty of parking) and closest to the CBD (none of the units are actually that close to the $\mathrm{CBD}$ or the coast). However, Somerset was also the oldest and smallest unit. Note that size will determine, to some extent, the type of household for which the unit is appropriate.

\subsection{Neighbourhood characteristics}

Aerial photographs helped us qualitatively assess the overall complex and neighbourhood characteristics. First, we examined the area's urban characteristics, a qualitative assessment of the neighbourhood for land use mix. Mostly residential use was considered suburban and mostly mixed use was considered urban. Each photograph was given a score from 1 to 5 with 5 being the most urban (mixed land use). After the surrounding area was considered, the complex was rated. Complex type was a descriptive label, such as multiple smaller buildings or high-rise. The parking at the complex was included as well. Parking was a dichotomous variable of whether or not the complex has dedicated parking lots/spaces for residents. Open space was also assessed. Open space was a dichotomous variable of whether or not the complex is adjacent or proximate (e.g., across the street) to open space. Tree cover was then measured. For tree cover, we evaluated the number of trees within the complex itself; this gave a score from 1 to 5 , with 5 having almost complete tree canopies and 1 having virtually no shaded areas. Finally, potential areas for interaction were noted; within interaction areas, residents can interact with their neighbours (courtyards, gardens, pools, tennis courts, walking paths, and so on). This variable offers an assessment of social capital opportunities. Again, this was a score from 1 to 5 , with 5 meaning many areas of interaction and 1 a very limited area for interaction. Please see Figures 6 to 9 and Table 9.

Once again, the lower-priced units, particularly Somerset, fared best by the criteria, showing more land use mix (urban), more areas for social interaction, and larger trees (offering a more mature landscape aesthetic). However, density was highest for the lower-priced unit(s); this is the trade-off in neighbourhood characteristics.

\section{Discussion}

Using both quantitative and qualitative methods to explore the Hillsborough County, Florida, condominium foreclosure market and the potential of converting condos to affordable housing, we found that units under foreclosure sold at discounted prices compared to units not under foreclosure. Although the discount was modest, the condos still offered opportunities for units affordable at various AMI matches. The cases assessed qualitatively suggested that, in addition to affordability, condos could also provide neighbourhood amenities and facilities to ensure a good quality of life with good access to public transit, high-quality elementary schools, proximity to open space, urban amenities, and social capital opportunities.

Table 9: Aerial findings for selected units

\begin{tabular}{lllll}
\hline Variable & Somerset & Richmond & Brookfield & Sifield \\
\hline Urban form & 3 & 2 & 1 & 1 \\
\hline Complex type & Several smaller buildings & Several smaller buildings & Several duplex units & Several duplex units \\
\hline Parking & Yes & Yes & Yes & Yes \\
\hline Open space & Yes & Yes & Yes & Yes \\
\hline Tree cover & Few larger trees & Few smaller trees & Few smaller trees & Few smaller trees \\
\hline Interaction areas & 4 & 2 & 1 & 1 \\
\hline
\end{tabular}



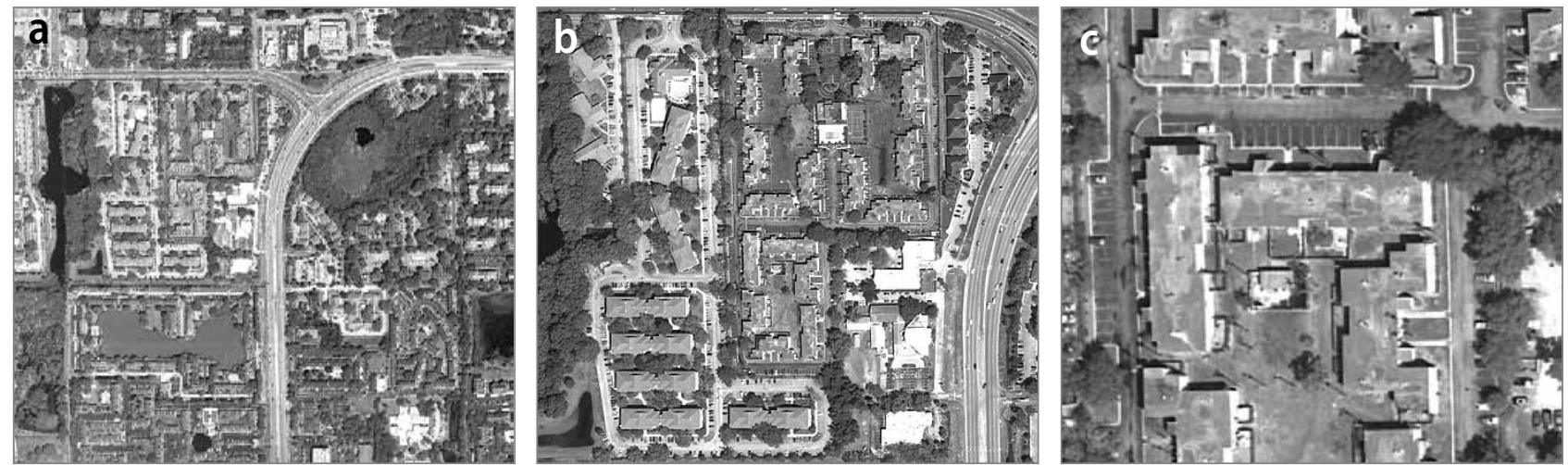

Figure 6: Somerset: a) neighbourhood; b) complex; c) building aerial photos (source: Google Maps, 2010).
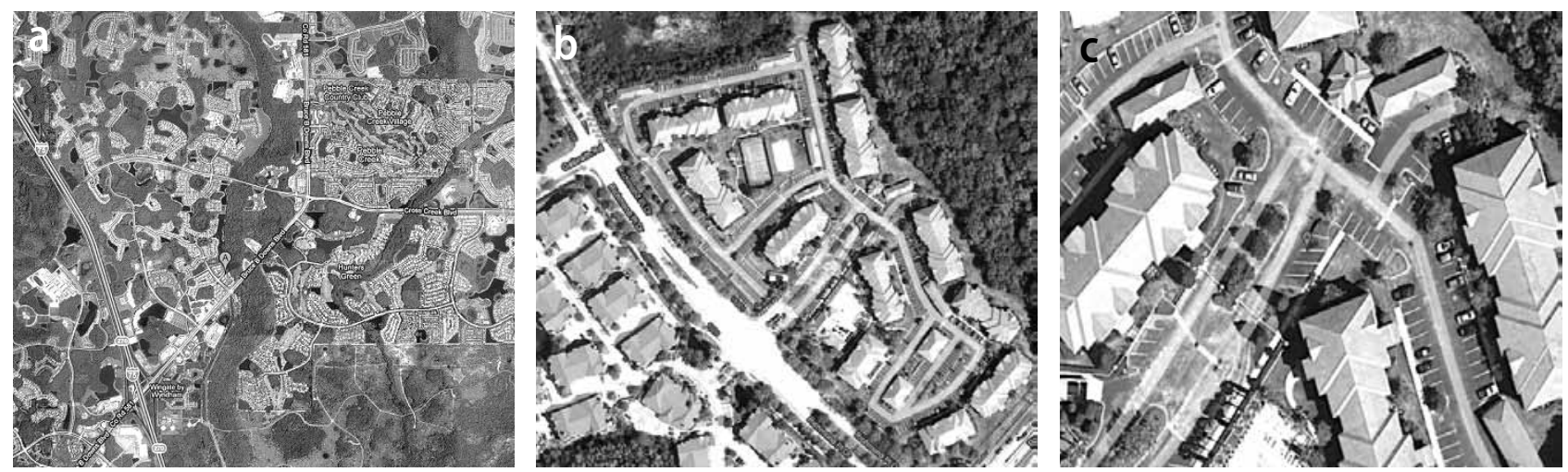

Figure 7: Richmond: a) neighbourhood; b) complex; c) building aerial photos (source: Google Maps, 2010).
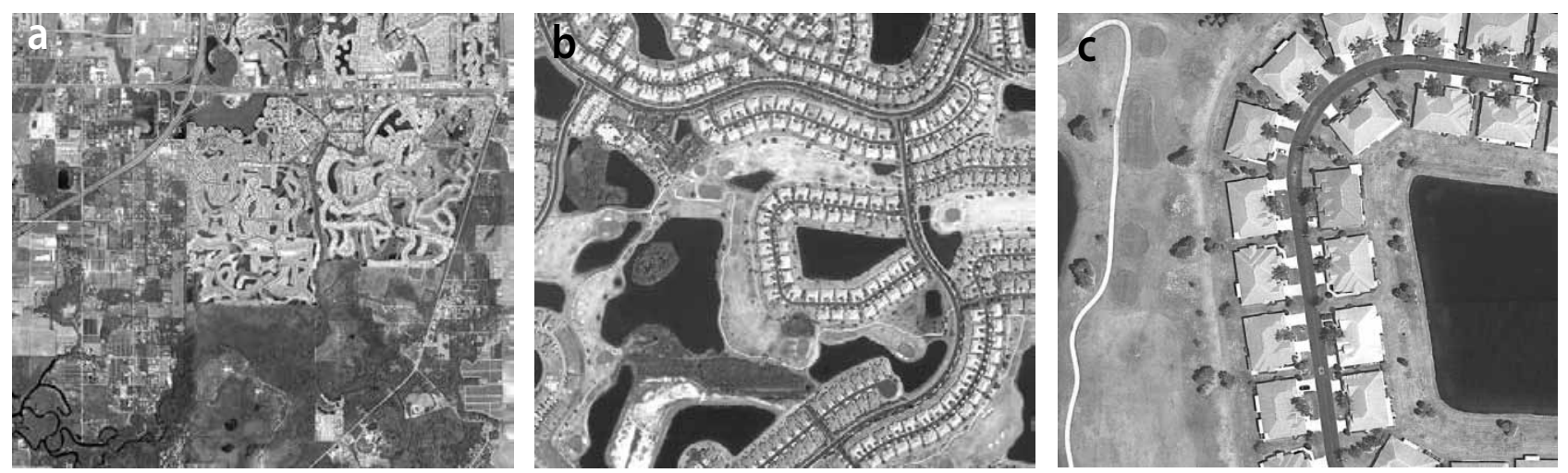

Figure 8: Brookfield: a) neighbourhood; b) complex; c) building aerial photos (source: Google Maps, 2010).
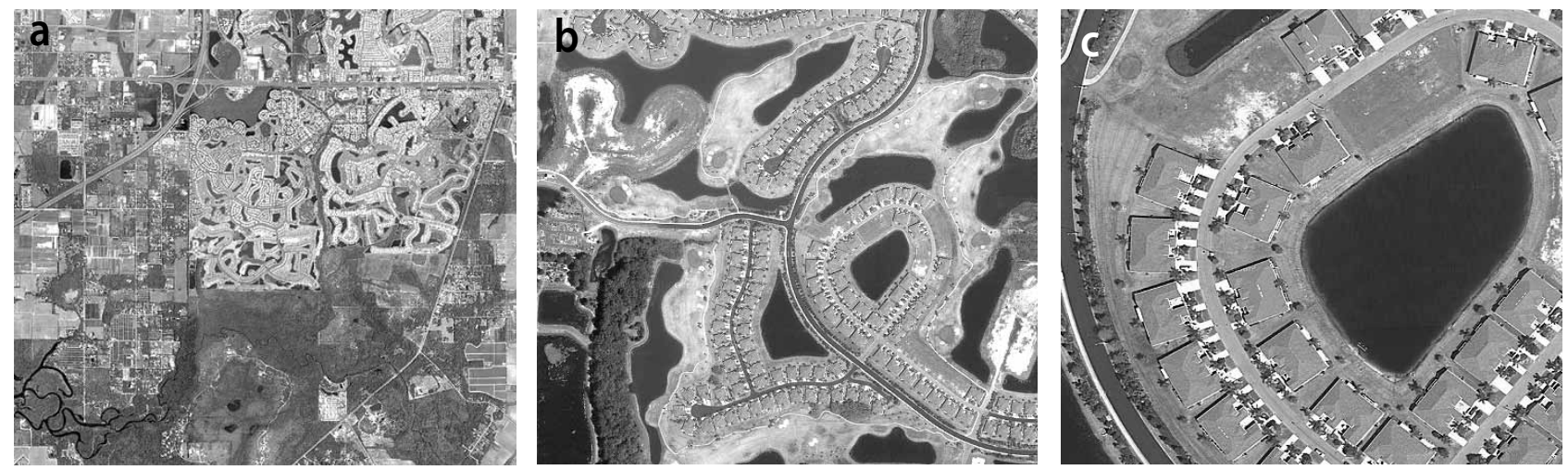

Figure 9: Sifield: a) neighbourhood; b) complex; c) building aerial photos (source: Google Maps, 2010). 
State and local governments could use this information to capitalise on foreclosure crises in addressing housing affordability in many communities, particularly in Florida. The planning implications involve discourse on housing markets and affordability, stabilisation, and recovery.

Factors related to condo price, such as distance to the urban core or to the beach, can help identify areas with affordable condo prices; these areas may generate more opportunities than other areas. However, many obstacles from both the supply and demand sides must be overcome in condo conversions. Mortgage underwriting policies need to accommodate low-to-moderate income households and treat condo financing like regular home financing. As indicated in the analysis, most foreclosed condominiums are affordable for households with less than 100\% AMI. Thus, a few major obstacles remain in converting condos to affordable housing. First of all, a 20\% down payment might prevent many buyers that qualify in income and credit from obtaining appropriate conventional mortgages. Down-payment assistance or reducing down-payment requirements in government-insured mortgages might help overcome this obstacle. Second, our cost estimates for affordable housing in this analysis are conservative for condominium fees. Condo fees can be as high as several hundred dollars a month in higher-end complexes. Accordingly, subsidies or an agreement between condo association and homeowners/ government might help solve this problem. Third, the number of foreclosed condos is limited; many more single-family homes are under foreclosure proceedings. Current state and federal programs related to foreclosure have helped stabilise neighbourhoods and provided more affordable housing stock, but the scope of these programs is very limited. A strong coalition among various agencies should help in working out innovative funding schemes for converting foreclosed homes to affordable housing. Subsides to offset the costs of condominium fees might help.

\section{Conclusion}

This paper is a first attempt to explore U.S. foreclosures based on types of housing and how foreclosed condominiums might be used to provide affordable housing in Florida, where condominiums account for a large portion of the housing stock. We used only Hillsborough County as an example because of limitations in data, so we did not cover southern Florida, where foreclosures are an even larger issue with condo vacancies even higher than in Hillsborough County. Future research should focus on expanding research areas and identifying foreclosed vacant condos for potential conversion. The research methodology can be replicated in local communities to calculate affordable housing stock. Qualitative assessments could explore whether the "condos to affordable housing" efforts in New York City has been successful in promoting adaptive reuses of vacant properties, particularly foreclosed vacant condominiums.

Huston John Gibson

Kansas State University, Faculty of Regional and Community Planning, Department of Landscape Architecture/Regional and Community Planning, Manhattan, Kansas, USA

E-mail: hgibson@k-state.edu

Yanmei Li

Florida Atlantic University, Faculty of Urban and Regional Planning, School of Urban and Regional Planning, Ft. Lauderdale, Florida, USA E-mail:yli22@fau.edu

\section{Notes}

[1] The data were retrieved from multiple issues of the quarterly periodical U.S. Housing Market Conditions compiled by the U.S. Department of Housing Development.

${ }^{[2]}$ This number is based on FHFA (Federal Housing Finance Agency) housing price index statistics.

${ }^{[3]}$ In 2008 USD 7,500 was given to first-time homebuyers. In 2009, the credit increased to USD 8,000 and USD 6,500 was offered to repeat homebuyers. Initially, the tax credit would have expired on 30 November 2009. Under the pressure of the real estate industry, the tax credit was extended to 30 April 2010.

${ }^{[4]}$ In our original study, we also sought information on investor speculation/flipping in this market, and how this might this affect a market rebound. Although we had no reason to suspect a high concentration of investor speculation/flipping because of high carrying costs associated with condominium association fees, there is some known activity, such as Condo Vultures, Inc., in southern Florida (Depken et al., 2009). However, our dataset does not have enough appropriate seller information to make a clear determination of the motives of buyers, and a future follow-up survey study is necessary.

${ }^{[5]}$ Suspicious and/or incomplete data were not included in analysis.

${ }^{[6]}$ The U.S. Census Bureau (2010) estimate for Hillsborough County was just over 1 million persons (1,195,317 county total in 2009 and 332,888 for the city of Tampa in 2006).

[7] January through May is considered the peak season in the Florida peninsula. Due to the agreeable climate during this season, many Florida residents, known as "snowbirds," live in the state only during this time. As a result, beaches, roadways, restaurants, and condominium complexes are noticeably more congested when compared to the off-season (June through December).

${ }^{[8]}$ Brookfield and Maplewood Condominiums are 55+ communities in Hillsborough County. This finding came after it had been randomly selected for case study. We chose to keep the unit to demonstrate another possible constraint for families in need of affordable housing, and due to the fact that elderly households also need affordable housing.

${ }^{\text {[9] }}$ Rates will fluctuate but, after talking with a mortgage loan officer on 27 April 2010, this rate was considered appropriate for conservatively estimating standard loan payments in 2008 dollars. 


\section{References}

Allen, M. T. \& Swisher, J. (2000) An analysis of the price formation process at a HUD auction. Journal of Real Estate Research, 20(3), pp. 279298.

Anderson, B. (2009). When could empty condos become affordable housing? City Limits, 7 Jun. 2009. Available at: http://www.indypressny. org (accessed 8 Jan. 2010).

Apgar, W. \& Duda, M. (2004) Mortgage foreclosure trends in Los Angeles: Patterns and policy issues. Los Angeles, Neighborhood Housing Services.

Belsky, E. S. (2005) Revisiting rental housing: A policy summit. Cambridge, MA, Harvard University, Joint Center for Housing Studies, Framing the Rental Policy Summit.

Betances, Y. (2010) Foreclosed buildings to become affordable homes. Eagle Tribune. 15 July 2010. Available at: http://www.eagletribune.com (accessed 15 Jul. 2010).

Bocian, D. G., Ernst, K. S. \& Li, W. (2008) Race, ethnicity and subprime home loan financing. Journal of Economics and Business, 60(1-2), pp. 110-124. DOI: 10.1016/j.jeconbus.2007.10.001

Carr, J. H. (2008) Responding to the foreclosure crisis. Washington, DC, National Community Reinvestment Coalition.

Carroll, T. M., Clauretie, Y. M, Neil, H. \& Jorgensen C. (1995) HUD versus private bank foreclosures: A spatial and temporal analysis. Journal of Housing Economics, 4(2), pp. 183-194. DOI: 10.1006/jhec.1995.1009

Chan, S., Gedal, M., Been, V. \& Haughwout, A. (2010) The role of neighborhood characteristics in mortgage default risk: Evidence from New York City. New York, New York University, Wagner School and Furman Center for Real Estate \& Urban Policy.

Davis, M. A. (2010) Reflections on the foreclosure crisis. Land Lines, July, pp. 1-8.

Depken, C. A., Hollans, H. \& Swidler, S. (2009) An empirical analysis of residential property flipping. Journal of Real Estate Finance and Economics, 39(3), pp. 248-263. DOI: 10.1007/s11146-009-9181-3

Duncan, D. T., Aldstadt, J., Whalen, J., Melly, S. J. \& Gortmaker, S. L. (2011). Validation of walk score for estimating neighborhood walkability: An analysis of four US Metropolitan Areas. International Journal of Environmental Research and Public Heath, 8(11), pp. 4160-4179. DOI: 10.3390/ijerph8114160

Florida Housing Data Clearing House (2010) Households by income and cost burden, Hillsborough County, 2009. Available at: http://flhousingdata.shimberg.ufl.edu (accessed 15 Aug. 2011).

Foote, C., Gerardi, K., Goette, L. \& Willen, P. (2010) Reducing foreclosures: No easy answers. NBER Macroeconomics Annual, 24(1), pp. 89138.

Forgey, F. A., Rutherford, R. C. \& Van Buskirk, M. L. (1994) Effect of foreclosure status on residential selling price. Journal of Real Estate Research, 9(3), pp. 313-318.

Gerrity, M. (2010) Miami condo investors successfully resell 400 condo foreclosures, making USD 83 per foot profit. 22 Mar. 2010. Available at: http://www.realestatechannel.com (accessed 15 Aug. 2011).

Google Maps (2010) Map of Tampa / Hillsborough County, Florida. Available at: http://maps.google.com (accessed 27 Jun. 2010).

Hardin, W. G. III \& Wolverton, M. L. (1996) The relationship between foreclosure status and apartment price. The Journal of Real Estate Research, 12(1), pp. 101-109.

Harding, J. P., Rosenblatt, E. \& Yao, V. W. (2009) The contagion effect of foreclosed properties. Journal of Urban Economics, 66(3), pp. 164-178. DOI: 10.1016/j.jue.2009.07.003
House Repos (2009) Foreclosed condos converted into affordable homes in New York City. Available at: http://www.houserepos.net (accessed on 20 July 2009).

Housing and Urban Development (2010) Affordable housing. Available at: www.hud.gov (accessed 27 Jun. 2010).

Immergluck, D. \& Smith, G. (2006a) The external costs of foreclosure: The impact of single-family foreclosures on property values. Housing Policy Debate, 17(1), pp. 57-79. DOI: 10.1080/10511482.2006.9521561

Immergluck, D. \& Smith, G. (2006b) The impact of single-family mortgage foreclosures on neighborhood crime. Housing Studies, 21(6), pp. 851-866. DOI: 10.1080/02673030600917743

Katz, A. (2009) Gentrification hangover: How New York could create affordable housing from its empty glass condo buildings and failed takeover projects. Prospect, 18. Dec. 2009. Available at: http://www. prospect.org (accessed 6 Jan. 2010).

Lin, Z., Rosenblatt, E. \& Yao, V. W. (2009) Spillover effects of foreclosures on neighborhood property values. Journal of Real Estate Finance Economics, 38(4), pp. 387-407. DOI: 10.1007/s11146-007-9093-z

Mehaffy, M. W. \& Haas, T. (2012) Poststructuralist fiddling while the world burns: Exiting the self made crisis of "architectural culture". Urbani izziv, 23(1), pp. 80-90. DOI: 10.5379/urbani-izziv-en-2012-23-01-001

Mortgage Calculator (2010) Mortgage calculator. Available at: http://www.mortgagecalculator.org (accessed 27 Jun. 2010).

National Association of Realtors (2012) Housing affordability index. Available at: http://www.realtor.org (accessed 24 Jul. 2012).

Nelson, K. P. (1994) Whose shortage of affordable housing? Housing Policy Debate, 5(4), pp. 401-442. DOI: 10.1080/10511482.1994.9521172

Padgett, T. (2009) Despite the crash in prices, affordable housing still lacking. Time, 25 Feb. 2009. Available at: http://www.time.com (accessed 15 Aug. 2011).

Pennington-Cross, A. (2003) Credit history and the performance of prime and nonprime mortgages. Journal of Real Estate Finance and Economics, 27(3), pp. 279-301. DOI: 10.1023/A:1025891223226

Poethig, E. (2010) The impact of the foreclosure crisis on public and affordable housing in the Twin Cities. Washington, DC, U.S. Department of Housing and Urban Development, Policy Research and Development.

Realtytrac (2008) U.S. foreclosure market statistics by state. Available at: http://www.realtytrac.com (accessed 31 Jan. 2010).

Right to the City Alliance (2010) People without homes and homes with out people: A count of vacant condos in select NYC neighborhoods 2010. New York.

Schuetz, J., Been, V. \& Ellen, I. G. (2008) Neighboring effects of concentrated foreclosures. Journal of Housing Economics, 17(4), pp. 306-319. DOI: 10.1016/j.jhe.2008.09.004

Shilling, J. D., Benjamin, J. D. \& Sirmans, C. F. (1990) Estimating net realizable value for distressed real estate. The Journal of Real Estate Research, 5(1), pp. 129-140.

Shop and Compare Rates (2010) Compare rates: Auto, home, life, mortgage and refinance. Available at: www.shopandcomparerates.com (accessed 4 Jun. 2010)

Springer, T. M. (1996) Single-family housing transactions: Seller motivations, price, and marketing time. Journal of Real Estate Finance and Economics, 13(3), pp. 237-254. DOI: 10.1007/BF00217393

United States Census Bureau (2008) State and county quickfacts. Available at: http://quickfacts.census.gov (accessed 4 Jun. 2010).

United States Census Bureau (2010) American FactFinder. Available at: http://factfinder2.census.gov (accessed 10 Aug. 2012). 
Walk Score (2010) City and neighborhood walkability rankings. Available at: http://www.walkscore.com (accessed 4 Jun. 2010).

Wallison, P. J. (2009) Cause and effect: Government poli-

cies and the financial crisis. Critical Review, 21(2), pp. 365-376.

DOI: 10.1080/08913810902934158

White, J. (2009) First-time homebuyer tax credit: Testimony on taxpayers' use of the credit and implementation and compliance challenges. Washington, DC, U.S. Government Accountability Office. 